PART I. DISEASES AND PROBLEMS DISTINGUISHED BY WHO AND FAO DZIAŁ I. CHOROBY I PROBLEMY WYRÓŻNIONE PRZEZ WHO I FAO

\title{
FEATURES OF BEHAVIOR, DIET, ALCOHOL CONSUMPTION, SMOKING, AND PSYCHOLOGICAL STATE AND THEIR RELATIONSHIPS WITH THE ACADEMIC PERFORMANCE OF JUNIOR MEDICINE STUDENTS
}

\section{CECHY ZACHOWANIA, DIETA, SPOŻYCIE ALKOHOLU, PALENIE PAPIEROSÓW ORAZ STAN PSYCHOLOGICZNY I ICH ZWIĄZEK Z OSIĄGNIĘCIAMI NAUKOWYMI STUDENTÓW NIŻSZYCH LAT MEDYCYNY}

\author{
Lidiia Korovina $^{1(\mathrm{~A}, \mathrm{~B}, \mathrm{C}, \mathrm{D}, \mathrm{E}, \mathrm{F})}$, Tetiana Zaporozhets ${ }^{2(\mathrm{~A}, \mathrm{D}, \mathrm{E})}$, Fiedor Boyechko ${ }^{3(\mathrm{D}, \mathrm{E})}$ \\ ${ }^{1}$ Department of Medical Informatics, Medical and Biological Physics, \\ Ukrainian Medical Stomatological Academy, Poltava, Ukraine \\ ${ }^{2}$ Department of Physiology, Ukrainian Medical Stomatological Academy, Poltava, Ukraine \\ ${ }^{3}$ Department of Biology and Biochemistry, The Bohdan Khmelnytsky National University of Cherkasy, Ukraine
}

Authors' contribution Wkład autorów:

A. Study design/planning zaplanowanie badań B. Data collection/entry zebranie danych C. Data analysis/statistics dane - analiza i statystyki D. Data interpretation interpretacja danych E. Preparation of manuscript przygotowanie artykułu F. Literature analysis/search wyszukiwanie i analiza literatury G. Funds collection zebranie funduszy

\section{Summary}

Background. Peculiarities of behavior and nutrition, living conditions, consumption of alcohol, smoking, and psychological state are factors that can influence students' academic performance. Material and methods. 327 healthy 1-2-year students aged $18.8 \pm 0.1$ years were interviewed about lifestyle, consumption of various types of foods and alcohol, intensity and duration of smoking, fasting experience, satisfaction with their degree of wealth and family relationships, sleep duration and sleep disorders, and the number of physical and psychological traumas. Anxiety, self-esteem, academic ability, and academic performance were determined. Results. Students' nighttime sleep duration was 7.1 \pm 0.1 hours; sleep disorders were observed in $40.1 \%$ of students. Vegetables were consumed daily by $31.4 \%$ students. $70.8 \%$ of males and $57.8 \%$ of females were satisfied with wealth. The females' academic performance was higher. Alcohol consumption was higher among females from wealthy families, but lower than among males. Conclusions. Academic performance was negatively related to the weekly dose of alcohol consumed. The academic ability level of abstainers was higher than that of alcohol users. Alcohol users showed an inverse relationship between alcohol consumption and anxiety. Differences were found in factors contributing to alcohol use by young men and women. Academic performance was lower in individuals who fasted for more than one day.

Keywords: students, alcohol consumption, behavior, academic success

\section{Streszczenie}

Wprowadzenie. Osobliwości zachowania i odżywania, warunków życia, spożycia alkoholu, palenie papierosów, a także stan psychologiczny są czynnikami wpływającymi na osiagnnięcia studentów. Materiał i metody. W badaniu wzięło udział 327 zdrowych studentów I i II roku medycyny w wieku $18,8 \pm 0,1$ lat. Zostali zapytani o styl życia, spożycie różnych pokarmów i alkoholu, intensywność i długość palenia papierosów, poszczenie, stopień zadowolenia ze zdrowia i relacji rodzinnych, długość i zaburzenia snu oraz doświadczenie traum fizycznych i psychologicznych. Określono na tej podstawie stopień niepokoju, poczucia własnej wartości, zdolności i osiagnięć akademickich. Wyniki. Czas snu studentów wynosił 7,1 $\pm 0,1$ godziny, a zaburzenia snu zaobserwowano u 40,1\% studentów. 31,4\% studentów spożywało codziennie warzywa. 70,8\% mężczyzn i 57,8\% kobiet było zadowolonych z własnego statusu materialnego. Osiągnięcia akademickie kobiet były wyższe. Większe spożycia alkoholu zanotowano u kobiet z zamożnych rodzin, niższe jednak niż wśród mężczyzn. Wnioski. Osiągnięcia były negatywnie skorelowane z tygodniowa dawka spożywanego alkoholu. Poziom zdolności akademickich był wyższy u abstynentów niż u osób spożywających alkohol. U osób spożywających alkohol wystąpiło sprzężenie zwrotne pomiędzy spożyciem alkoholu a stopniem niepokoju. Zaobserwowano różnice w czynnikach przyczyniajacych się do spożywania alkoholu przez młodych mężczyzn i kobiety. Mniejsze osiągnięcia wykazały osoby poszczące dłużej niż jeden dzień.

Słowa kluczowe: studenci, spożycie alkoholu, zachowanie, sukces akademicki

Tables: 0

References: 28

Submitted: 2020 Sep 4

Accepted: 2021 Jan 11

Korovina L, Zaporozhets T, Boyechko F. Features of behavior, diet, alcohol consumption, smoking, and psychological state and their relationships with the academic performance of junior medicine students. Health Prob Civil. 2021; 15(1): 4-11. https://doi.org/10.5114/hpc.2021.102570

Address for correspondence / Adres korespondencyjny: Lidiia Korovina, Department of Medical Informatics, Medical and Biological Physics, Ukrainian Medical Stomatological Academy, Nebesna Sotnia St. 77, 36037 Poltava, Ukraine, e-mail: korovinalidiia@gmail.com, phone: +38(0532) 68 73 86

ORCID: Lidiia Korovina https://orcid.org/0000-0003-4989-997X, Tetiana Zaporozhets https://orcid.org/0000-0002-1832-7680,

Fiedor Boyechko https://orcid.org/0000-0002-4201-4027

Copyright: (c) Pope John Paul II State School of Higher Education in Biała Podlaska, Lidiia Korovina, Tetiana Zaporozhets, Fiedor Boyechko. This is an Open Access journal, all articles are distributed under the terms of the Creative Commons Attribution-NonCommercial-ShareAlike 4.0 International (CC BY-NC-SA 4.0) License (http://creativecommons.org/licenses/by-nc-sa/4.0/), allowing third parties to copy and redistribute the material in any medium or format and to remix, transform, and build upon the material, provided the original work is properly cited and states its license. 


\section{Introduction}

Many factors influence academic performance, including students' social, demographic, emotional, and academic circumstances [1]. Burrows et al. showed that academic performance depends on diet and nutritional habits. Irregular eating and skipping breakfast have a negative impact; high fruit intake and an overall high quality diet contribute to learning success [2]. Academic stress also negatively impacts academic performance, as well as students' health and quality of life [3]. In a review, Febrilia et al. summarized data on the influence of negative mood, which reduces learning outcomes [4]. The effect of smoking on academic performance is characterized as weak [5]. Factors that significantly disrupt academic performance include the use and abuse of psychoactive substances and alcohol. Alcohol consumption has specific characteristics in different countries and population groups, including medical personnel [6]. Various surveys of students in Ukraine report that alcoholic beverages are consumed by $58.7 \%$ to $71 \%$ of males and $39 \%$ to $58.7 \%$ of females. Furthermore, surveys report that $29.3 \%$ of students smoke [7,8]. The number of students completely abstaining from alcohol can be extremely low $[9,10]$. This phenomenon has a wide range of social and psychological causes [11-13]. Family preconditions such as drinking parents, increased anxiety, post-traumatic stress disorder, and genetic factors also play a role [14]. A review of 61 studies by Reid and Carey identified 22 factors with the potential to reduce student alcohol consumption and subsequently improve the effectiveness of educational work [15]. But the problem requires further research to create more effective methods for reducing alcoholism.

The objective of the current research was to study the effects of the following factors on the academic performance of medical students on junior courses: behavior, nutrition, living conditions, the level of alcohol and smoking consumption, and psychological state. Particular attention was paid to the analysis of the causes and consequences of alcohol consumption.

\section{Material and methods}

\section{Study design}

The study was carried out according to the plan of a multivariate correlation study.

\section{Participants}

A total of 327 (138 male and 189 female) healthy students of 1-2 years of the Ukrainian Medical Stomatological Academy in Poltava, Ukraine, who permanently resided in Ukraine, filled out questionnaires. The mean age of the subjects was $18.8 \pm 0.1$ years. All respondents agreed to participate in the study, which was approved by the Ukrainian Medical Stomatological Academy Ethics and Bioethics Commission and was conducted in accordance with the requirements of the Council of Europe Convention on Human Rights and Biomedicine (1997), and the Helsinki Declaration of the World Medical Association on ethical principles. The study was conducted in the winter-spring period of 2015-2016. Response rate was $93.4 \%$.

\section{Data processing and analysis}

All students gave their written consent to the processing of data and independently filled out paper forms. The main questionnaire developed for this study included questions about the frequency, duration, and characteristics of alcohol consumption; smoking; frequency and quantity of various types of food consumed; lifestyle; presence of heart and regulatory diseases in family; degree of satisfaction with material well-being, family relationships, education, and life in general [16]. Ordinal scales were used to assess the indicators. Life satisfaction was assessed using an 11-level scale $(-5$ to +5$)$; satisfaction with family relationships, living conditions, and education was assessed on a 3-level scale (good, satisfactory, unsatisfactory); and material security used a four-level scale. The frequency of consumption of various products was determined according to an ordinal 4-level scale (daily, 2-3 times a week, at least 2 times a week, no use).

The total indicator of food diversity was calculated based on the consumption frequency of products from different groups. Students were asked about the duration of sleep and the frequency of sleep disturbances, the number and average duration of abstinences from food in the last year, the average daily number of cigarettes smoked, and the duration of regular smoking and drinking. To assess trauma, they were asked about the number of physical and psychological traumas they experienced before 15 years of age, from age 15 to a year before the study, and in the last year. 
The average weekly dose of pure alcohol, including dose per kilogram of body weight, was calculated based on the frequency, volume, and strength (40 vol\%; $16-20 \mathrm{vol} \%$; $9-12 \mathrm{vol} \%$; up to 8 vol\%) of the drinks consumed. A separate questionnaire asked questions from the multidimensional questionnaire MMPI (in the Russian version) to determine anxiety, self-esteem, and academic ability, as well as a control group of questions to detect the level of false information in order to exclude systematic errors in the obtained data (scale L) [17]. To assess academic performance, the average score for all academic disciplines was calculated at the end of the academic year.

\section{Statistical analysis}

Interval data were expressed as Mean \pm SEM; ordinal data were subjected to frequency analysis. Comparison of indicators of different groups of students was carried out using the Mann-Whitney method. The data were subjected to correlation analysis with the calculation of the Kendall coefficient $\tau$, since most of the indicators were ordinal. The limit of statistical significance was considered $\mathrm{p}<0.05$. For indicators of anxiety, self-esteem, and academic ability, Cronbach's alpha values were $0.82,0.76$, and 0.77 , respectively. For a group of questions about the number of psychological traumas in different periods of life, Cronbach's alpha was 0.81; for a group of questions about the frequency of consumption of various foods, Cronbach's alpha was 0.68.

\section{Results}

In accordance with the set goal, we analyzed the behavioral characteristics of students. It was found that the duration of night sleep was $7.1 \pm 0.1$ hours. Episodic daytime sleep lasting $1.6 \pm 0.1$ hours was noted by $45.0 \%$ of the respondents. Sleep disturbances were noted by $40.1 \%$ of students, at a frequency of $1.3 \pm 0.1$ times a week. The duration of walking was $2.5 \pm 0.1$ hours per day; the time spent sitting was $7.7 \pm 0.1$ hours per day.

Analysis of diet showed that $31.4 \%$ of respondents ate vegetables daily, and only $21.6 \%$ ate fresh vegetables and fruits daily; $44.3 \%$ of respondents ate vegetables 2-3 times a week, with $40.9 \%$ eating fresh vegetables and fruits 2-3 times a week. We found differences in nutrition between males and females: $72.4 \%$ of males consumed lard compared to $51.3 \%$ of females, and there were 4.3 times more males who consumed it regularly $(p<0.001)$. Young men also consumed fatty meats, eggs, and milk more frequently.

The vast majority of respondents noted satisfaction with their lives: $72.8 \%$ rated from +3 to +5 ; the mean score was $+3.1 \pm 0.1$, with no statistically significant effect of gender. The presence of traumatic situations before the age of 15 was reported by $12.3 \%$ of respondents, from 15 to a year before the survey by $11.1 \%$, and for the last year by $12.2 \%$. In total $10.2 \%$ of students reported only one traumatic event in a lifetime, whereas $11.1 \%$ of respondents reported multiple traumatic events. Males expressed significantly more satisfaction with wealth than females (70.8\% and 57.8\%, respectively; $\mathrm{p}<0.05)$.

Regular alcohol consumption lasting more than a year was indicated by $51.5 \%$ of respondents $(62.1 \%$ of males and $43.2 \%$ of females), and the percentage of students drinking alcohol increased with age (Figure 1).

\section{Share of consumers, \%}

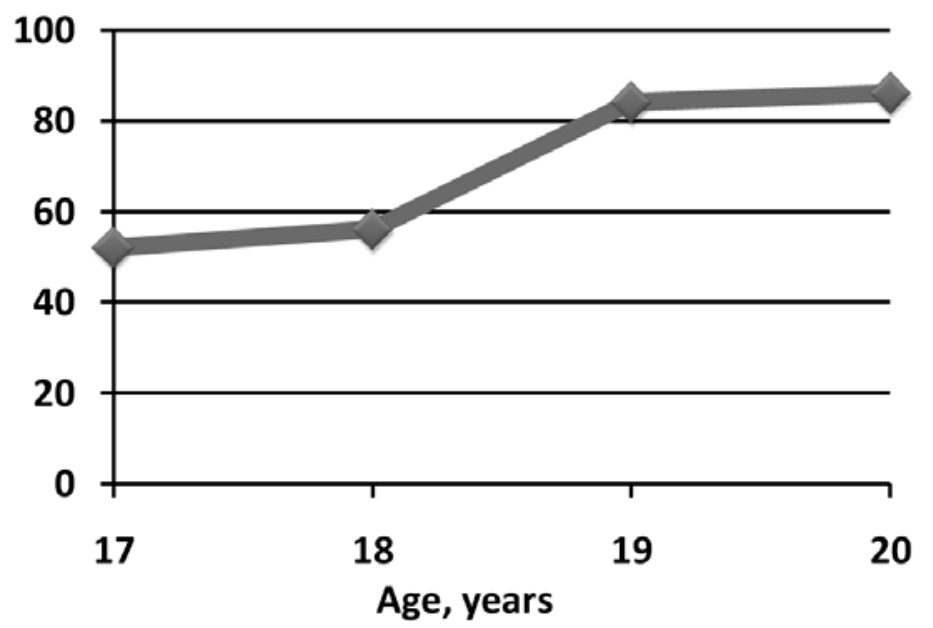

Figure 1. The percentage of students drinking alcohol by age 
The structure of alcohol consumption also differed by age, with a gradual increase in the consumption of spirits (Figure 2). There are correlations of consumption duration with a single dose of alcohol consumed per unit body weight $(\tau=0.55, \mathrm{p}<0.001)$, and with a weekly dose of alcohol $(\tau=0.61, \mathrm{p}<0.001)$.

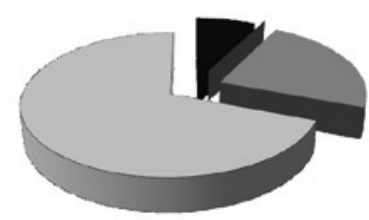

17 years

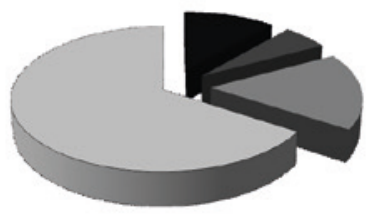

18 years

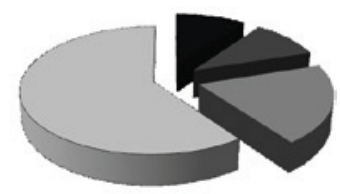

19 years
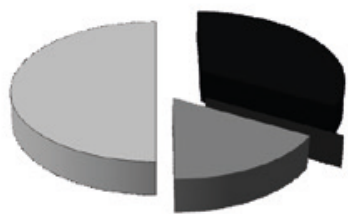

20 years
$-40 \%$

- $16-17 \%$

9-12\%

$\square$ 5-8\%

Figure 2. The distribution of students' preferences for alcoholic beverage strength across age groups

Drunkenness is commonly considered to be the consumption of alcoholic beverages in terms of pure ethanol, about $300 \mathrm{~g}$ for men and $200 \mathrm{~g}$ for women per week, or $70 \mathrm{~g}$ for men and $56 \mathrm{~g}$ for women per day [18,19]. In our study, only $2.9 \%$ of males and $1.2 \%$ of females $(p>0.05)$ reported that weekly doses exceeded these limits. Single doses were exceeded more often, and significantly more in males $(8.3 \%)$ than females $(1.7 \% ; \mathrm{p}<0.01)$.

Smoking was also more common among males $(47.8 \%)$ than among females $(19.6 \% ; \mathrm{p}<0.001)$; the average number of cigarettes smoked per day among smokers was $11.1 \pm 0.7$ for males and $6.3 \pm 0.5$ for females $(\mathrm{p}<0.001)$.

There was no effect of gender on self-esteem or academic abilities, but anxiety was higher in females (47.9 \pm 0.8 T-points in males versus $51.5 \pm 0.7 \mathrm{~T}$-points in females, $\mathrm{p}<0.002$ ). Anxiety level was inversely correlated with satisfaction with family relationships $(\tau=-0.16, p<0.001)$, life satisfaction $(\tau=-0.21, p<0.001)$, learning satisfaction $(\tau=-0.16, \mathrm{p}<0.001)$, and wealth $(\tau=-0.16, \mathrm{p}<0.001)$. Furthermore it was directly correlated with the frequency of sleep disorders $(\tau=0.25, p<0.001)$, the presence of meteorological dependence $(\tau=0.16, p<0.001)$, the severity of signs of autonomic dysfunction $(\tau=0.28, p<0.001)$, the number of psychotraumatic situations $(\tau=0.18, p<0.001)$, and the presence of coronary heart disease in the family $(\tau=0.15, p<0.01)$.

Academic ability correlated positively with family relationships satisfaction $(\tau=0.16, p<0.001)$ and learning satisfaction $(\tau=0.17, p<0.001)$ whereas it correlated negatively with the frequency of sleep disorders $(\tau=-0.17$, $\mathrm{p}<0.001)$, the severity of signs of autonomic dysfunction $(\tau=-0.21, p<0.001)$, and the number of traumatic situations $(\tau=-0.14, p<0.005)$. Most of these predictors were not strongly associated with alcohol consumption. However, it should be noted that the presence of meteorological dependence contributed to a decrease in weekly alcohol consumption per unit of body weight $(25.4 \pm 9.4 \mathrm{~g} / \mathrm{kg}$ in meteosensitive subjects versus $51.3 \pm 8.7 \mathrm{~g} / \mathrm{kg}$ in non-meteodependent students, $\mathrm{p}<0.05)$ and is accompanied by increased anxiety $(52.3 \pm 0.9$ T-points in meteosensitive individuals versus $48.5 \pm 0.7 \mathrm{~g} / \mathrm{kg}$ in non-meteosensitive individuals, $\mathrm{p}<0.001$ ).

Dependences of quantitative indicators of alcohol consumption on a number of psychological indicators and on the characteristics of behavior have been revealed. As the duration of alcohol use increases, academic ability, determined by the MMPI scale, decreases $(\tau=-0.17, p<0.001)$, learning satisfaction decreases $(\tau=-0.16$, $\mathrm{p}<0.002)$. The same dependences are observed for weekly alcohol doses $(\tau=-0.10, p<0.02$ and $\tau=-0.15, p<0.005$, respectively). An increase in the single and weekly doses of alcohol consumed was accompanied by a decrease in satisfaction with learning in females ( $\tau=-0.26, \mathrm{p}<0.001$, respectively). As a result, the academic performance of both males and females was negatively dependent on the weekly dose of alcohol consumed $(\tau=-0.20, p<0.001)$. Among males, the average academic score was $133.8 \pm 2.2$ points for alcohol drinkers and $138.4 \pm 3.0$ points for non-drinkers; among women average academic score were $140.2 \pm 4.6$ points and $145.6 \pm 2.0$ points, respectively.

The level of academic ability among students abstaining from alcohol was higher than among students regularly drinking alcohol (50.8 $\pm 0.8 \mathrm{~T}$-points and $48.8 \pm 0.8 \mathrm{~T}$-points, respectively; $\mathrm{p}<0.05)$. But among alcohol consumers, an inverse relationship was found between the weekly dose of alcohol and the level of anxiety $(\tau=-0.14, p<0.02)$. It is noteworthy that in this group, anxiety was associated with the number of psychological traumas during life $(\tau=0.28, p<0.001)$, which were not in the abstinent group. The average number of psychological traumas in the consumer group was $0.83 \pm 0.18$ versus $0.34 \pm 0.09$ among non-drinkers. This clearly indicates anxiety reduction is one of the reasons for alcohol consumption.

We did not observe a direct relationship between the level or duration of alcohol consumption and selfesteem. However, among females consuming alcohol, more pronounced associations of self-esteem with other possible predictors of drunkenness, such as satisfaction with family relationships $(\tau=0.32, p<0.001)$ and anxiety $(\tau=-0.35, p<0.001)$ were revealed, than in the group of girls abstainers $(\tau=0.25, p<0.01$ and $\tau=-0.18, p<0.05$, respectively). We did not find similar associations of self-esteem in young men consuming alcohol, and the group of abstainers was insufficient to confirm such dependences. However, among men consuming alcohol, there was 
a negative relationship between learning satisfaction and anxiety $(\tau=-0.28, p<0.001)$.

We were able to identify several family predictors of alcohol consumption among the data provided by students. Alcohol consumption was influenced in different ways by external and behavioral factors. For example, in the group of non-drinkers, the total number of events that were perceived as psychological trauma averaged $0.28 \pm 0.13$ in males and $0.37 \pm 0.12$ in females, whereas among alcohol consumers the total was $0.55 \pm 0.24$ and $1.14 \pm 0.27$, respectively. However, in the group of non-drinkers, there was a positive relationship between the number of psychological traumas and academic performance $(\tau=0.25, p<0.005)$, which was not significant in drinkers. It is probably associated with the same personal qualities as others differences. Thus, non-drinkers had a dependence of satisfaction with learning on the mean score $(\tau=0.22, p<0.01)$, while those who drink had no such dependence.

With an increase in single doses of alcohol consumed, the diversity of females' nutrition decreases $(\tau=-0.15$, $\mathrm{p}<0.02)$. This effect is not observed in young men. In general, the association of alcohol consumption and external conditions was more pronounced in females and had a stronger effect on academic performance as the duration of alcohol consumption increased $(\tau=-0.20, \mathrm{p}<0.05)$.

Only females had an association between a single dose of alcohol consumed and the number of events perceived as psychological trauma over a year before the study $(\tau=0.19, p<0.02)$, during the year before the study $(\tau=0.23, p<0.002)$, and with the number of cases of fasting per year $(\tau=0.15, p<0.05)$. Interestingly, young men showed an inverse relationship between the number of physical injuries and surgical interventions in the pre-study period and the level of alcohol consumption $(\tau=-0.20, p<0.01)$.

In females, the level of life satisfaction was negatively related to the duration of alcohol consumption and the weekly dose of alcohol consumed $(\tau=-0.20, p<0.002$ and $\tau=-0.25, p<0.001$, respectively). The same dependence was seen in smoking duration $(\tau=-0.14, p<0.05)$. In young men, such dependence was not determined. However, in young men, even at such a young age, there was a noticeable dependence of the number of respiratory diseases on the duration and intensity of smoking $(\tau=0.18, p<0.02$ and $\tau=0.15, p<0.05$, respectively). No such dependences were found in young women, probably due to the low frequency and intensity of smoking in the study group.

In females, both satisfaction with wealth and satisfaction with learning were negatively associated with the intensity of alcohol consumption $(\tau=-0.24, p<0.001$ and $\tau=-0.26, p<0.001$, respectively), as well as deterioration in sanitation. Unsatisfactory sanitary and hygienic conditions contributed to an increase in the weekly dose of alcohol $(\tau=-0.22, p<0.002)$. It is noteworthy that dissatisfaction with wealth motivates young women to study; among females, those with an unsatisfactory income had a mean academic score of $144.8 \pm 2.5$ points, while the wealthy students had a significantly lower average of $137.7 \pm 1.5$ points $(\mathrm{p}<0.01)$. On the contrary, satisfaction with life was significantly lower for those with an unsatisfactory income $(2.55 \pm 0.16$ points) compared to the wealthy ( $3.36 \pm 0.11$ points; $\mathrm{p}<0.001)$.

For students who did not fast, the average academic performance score was $141.4 \pm 1.3$ points; this was slightly lower for those who reported cases of fasting for 1 day (136.9 \pm 6.4 points), and lower still for those who fasted for 2 days or more (130.3 \pm 3.6 points; Figure 3$)$.

\section{Average score}

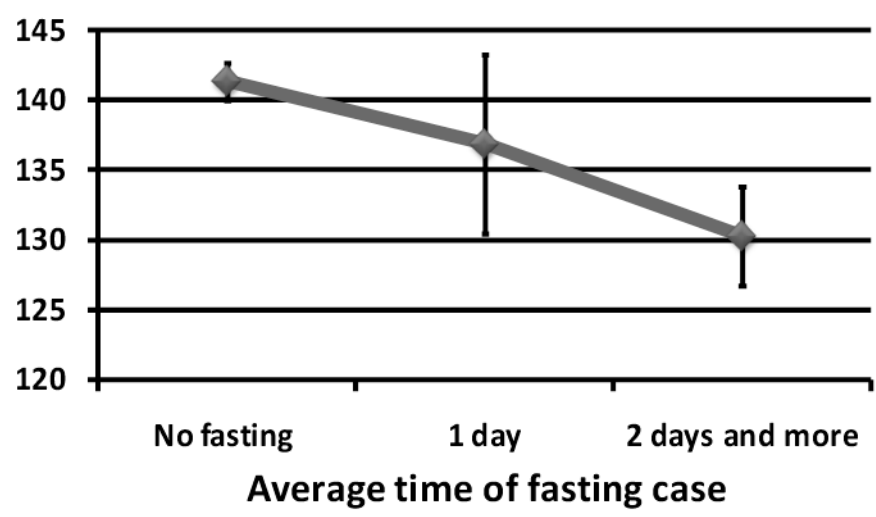

Figure 3. Dependence of students' academic performance on the duration of fasting

That is, one-day abstinence from food did not significantly affect academic performance, while longer incidents were associated with decreased performance. The average number of cases of fasting per year was 3.2 
days, varying widely up to 15 times a year, the duration of one case of fasting could reach 5 or even 10 days in one case. It is important that in females fasting cases were not associated with wealth or health conditions, i.e., had psychological motivation. It did, however, have a positive relationship with the number of psychological traumas $(\tau=0.15, \mathrm{p}<0.01)$ and with a deterioration in family relations $(\tau=-0.15, \mathrm{p}<0.005)$.

\section{Discussion}

Thus, in the group of identified factors that influenced academic performance, the most pronounced were gender, alcohol consumption, fasting for longer than a day, and wealth. Of these, alcohol consumption, common for both males and females, was of particular interest.

A prerequisite for both preventing psychoactive substance use and reducing the risk of alcoholism is the attitude that is formed in older school age. In Ukraine, adolescents' alcohol consumption corresponds to the average European level, making it 3-5 times higher than in the countries with the lowest consumption level. In most countries, alcohol consumption is higher among adolescents from high-income families, but the opposite pattern has been reported in Ukraine [20].

The current study observed an inverse relationship between the intensity of alcohol consumption and material wealth satisfaction in females, but no relationship in males. The duration of alcohol consumption among young women also had an inverse relationship with wealth satisfaction, indicating an earlier onset of alcohol use in families with high levels of financial support, which is concordant with WHO data obtained in most European countries. This can be explained by the fact that the majority of students are children from families with relatively high wealth - higher than among the general population.

A large review by Gilles et al. analyzed the most important factors contributing to alcoholism among students and showed that the longer the duration of alcohol consumption, the higher the risk of heavy drinking [21]. This is consistent with our dependence on the duration and weekly dose of alcohol. In our group of respondents, it was determined that unfavorable psychological conditions are especially conducive to the use of alcohol in young women, which in turn negatively affects their success and self-confidence. However the frequency of alcohol consumption was not associated with the level of anxiety.

Thus, we found that alcohol consumption, a significant cause of which is socio-psychological, reduces academic abilities and academic performance. This subsequently increases cravings for psychoactive substances, gradually forming a positive feedback loop, which consistently degrades each of its links. Direct dependences of the duration of smoking on the duration of alcohol consumption, and the intensity of smoking on weekly doses of alcohol are typical, in line with results obtained by Samara and Krieger et al. [22,23]. Alcohol decreases student performance by reducing the time spent on study, and scores are equally reduced for males and females $[24,25]$. This is consistent with data on the neurotoxic effect of alcohol on the brain of a young person [26].

Bailes analyzed a series of studies conducted in different countries in order to develop a means of counteracting alcoholism among students based on Bandura's theory of the triad of mutual determinism. According to this theory, a triad of influences should be taken into account: environmental (living conditions, the presence of informal student groups), behavioral (social norms), and personal (expectations of the effects of use, emotional intelligence, personal self-sufficiency) $[27,28]$. Depending on the combination of these factors, students may be offered different strategies for overcoming alcoholism.

\section{Conclusions}

Our study of behavioral characteristics, dietary patterns, living conditions, alcohol consumption, and smoking among junior medical students showed that the duration of night sleep among students was $7.1 \pm 0.1$ hours, however, sleep disorders were observed in a significant percentage of students $335.5 \%$ of males and $43.4 \%$ of females). The dietary patterns of the interviewed students were insufficient: the majority of students failed to consume vegetables, especially fresh ones, daily.

The vast majority of respondents noted satisfaction with their lives: $72.8 \%$ rated from +3 to +5 on a scale from -5 to +5 ; the average score was $+3.11 \pm 0.09$, with no effect of gender. The presence of traumatic situations was noted by $21.3 \%$ of respondents. $70.8 \%$ of males and $57.8 \%$ of females were satisfied with wealth.

Investigating the relationship of the above factors with academic performance showed that the most significant factors influencing academic performance were gender (female performance was higher), alcohol consumption, material security, and the practice of abstaining from food for more than one day. Although there was no significant difference in performance between alcohol drinkers and non-drinkers, students who abstained from alcohol had a higher level of academic ability than students who regularly drank alcohol. Within 
the drinking group, both male and female performance negatively depended on the weekly alcohol intake, despite relatively low alcohol consumption.

To understand the reasons for alcohol consumption, it seems important that alcohol users showed an inverse relationship between the weekly alcohol intake and the level of anxiety. Alcohol consumption was higher among females from wealthy families, but they also had more variety in their diet. However, among female alcohol consumers, life satisfaction was negatively associated with the weekly alcohol intake and the duration of alcohol consumption. In males, such dependencies were not determined, which confirms the differences in the formation of the propensity to drink and the increase in alcohol doses, as well as the consequences of this in men and women.

The task of our further research will be a more detailed study of the causes and effects of abstinence from food and dietary habits on student performance. The features of motivation, which contribute to academic success and manifest in higher academic performance of students with lower material wealth, also require further study.

\section{Disclosures and acknowledgements}

The authors report no conflict of interest.

\section{References:}

1. Pritchard ME, Wilson GS. Using emotional and social factors to predict student success. Journal of College Student Development. 2003; 44(1): 18-28. https://doi.org/10.1353/csd.2003.0008

2. Burrows TL, Whatnall MC, Patterson AJ, Hutchesson MJ. Associations between dietary intake and academic achievement in college students: a systematic review. Healthcare (Basel). 2017; 5(4): 60. https://doi. org/10.3390/healthcare5040060

3. Pascoe MC, Hetrick SE, Parker AG. The impact of stress on students in secondary school and higher education. International Journal of Adolescence and Youth. 2020; 25(1): 104-112. https://doi.org/10.1080/02673843.2 019.1596823

4. Febrilia I, Warokka A, Abdullah HH. University students' emotion state and academic performance: new insights of managing complex cognitive. Journal of e-Learning \& Higher Education. 2011; 2011: 879553. https://doi.org/10.5171/2011.879553

5. Kharma MY, Alqahtani W, Albishi WW, Bakhsh AK, Abram MA, Alsahly M. Effect of smoking on academic performance among dental students. International Dental Journal of Student Research. 2020; 8(1): 18-21. https://doi.org/10.18231/j.idjsr.2020.004

6. Dąbek J, Skorus P, Lepich T, Bajor G, Gąsior Z. Knowledge of coronary arteriosclerosis risk factors and their occurrence and the lifestyles of the first-year medical students. Health Prob Civil. 2018; 12(2): 78-87. https:// doi.org/10.5114/hpc.2018.75489

7. Chemeris NM. [Medico-social substantiation of the optimized prevention model of psychoactive substances use by student youth] [dissertation]. Uzhgorod: Uzhgorod National University; 2019 (in Ukrainian).

8. Serdyuk AM, Gulich MP, Petrenko OD, Lyubarska LS, Koblanska AV. [Awareness and understanding of students by health threats to health of risk factors for the development of non-infectious diseases - the present state of the problem]. Medicni perspektivi. 2019; 24(1): 4-14 (in Ukrainian). https://doi.org/10.26641/23070404.2019.1.162168

9. Labrie JW, Hummer JE, Pedersen ER. Reasons for drinking in the college student context: the differential role and risk of the social motivator. Journal of Studies on Alcohol and Drugs. 2007; 68(3): 393-398. https://doi. org/10.15288/jsad.2007.68.393

10. Zadarko-Domaradzka M, BarabaszZ,Sobolewski M,Nizioł-BabiarzE,Penar-Zadarko B,Szybisty A, etal.Alcohol consumption and risky drinking patterns among college students from selected countries of the Carpathian Euroregion. BioMed Research International. 2018; 2018: 6084541. https://doi.org/10.1155/2018/6084541

11. Eze NM, Njoku HA, Eseadi C, Akubue BN, Ezeanwu AB, Ugwu UC, et al. Alcohol consumption and awareness of its effects on health among secondary school students in Nigeria. Medicine. 2017; 96(48): e8960. https:// doi.org/10.1097/MD.0000000000008960

12. Mandziuk M, Wasilewska M, Lukács A. Alcohol consumption among students in the Lublin region of Poland. Health Prob Civil. 2020; 14(1): 18-23. https://doi.org/10.5114/hpc.2020.92981

13. Merrill JE, Wardell JD, Read JP. Drinking motives in the prospective prediction of unique alcohol-related consequences in college students. J Stud Alcohol Drugs. 2014; 75(1): 93-102. https://doi.org/10.15288/ jsad.2014.75.93 
14. Brown-Rice KA, Scholl JL, Fercho KA, Pearson K, Kallsen NA, Davies GE, et al. Neural and psychological characteristics of college students with alcoholic parents differ depending on current alcohol use. A Progress in Neuro-Psychopharmacology and Biological Psychiatry. 2018; 81: 284-296. https://doi.org/10.1016/j. pnpbp.2017.09.010

15. Reid AE, Carey KB. Interventions to reduce college student drinking: state of the evidence for mechanisms of behavior change. Clinical Psychology Review. 2015; 40: 213-224. https://doi.org/10.1016/j.cpr.2015.06.006

16. Korovina LD. [Certificate of copyright registration for the work No. 45947 dated 2012 Oct 9. Scientific work questionnaire of students of medical higher education institution to determine alimentary, behavioral and microsocial factors at the time of the survey, in childhood and subjective assessment of health]. Decision of the State Intellectual Property Service of Ukraine No. 46236 of 2012 Aug 7 (in Ukrainian).

17. Burlachuk LF, Morozov SM. [Dictionary reference for psychodiagnostics]. Sankt-Peterburg: Piter; 2006 (in Russian).

18. Ham LS, Hope DA. College students and problematic drinking: a review of the literature. Clinical Psychology Review. 2003; 23: 719-759. https://doi.org/10.1016/S0272-7358(03)00071-0

19. Vik P, Carrello P, Tate S, Field C. Progression of consequences among heavy-drinking college students. Psychology of Addictive Behaviors. 2000; 14(2): 91-101. https://doi.org/10.1037/0893-164X.14.2.91

20. Inchley J, Currie D, Vieno A, Torsheim T, Ferreira-Borges C, Weber MM, et al., editors. Adolescent alcoholrelated behaviours: trends and inequalities in the WHO European Region, 2002-2014. Observations from the Health Behaviour in School-aged Children (HBSC) WHO collaborative cross-national study. Copenhagen: WHO Regional Office for Europe; 2018.

21. Gilles DM, Turk CL, Fresco DM. Social anxiety, alcohol expectancies, and self-efficacy as predictors of heavy drinking in college students. 2006; 31(3): 388-398. https://doi.org/10.1016/j.addbeh.2005.05.020

22. Samara OY. [Alcohol and drug use in response to stress. Analysis of student youth behavior patterns]. Nauka i osvita. 2015; 3: 93-100 (in Ukrainian).

23. Krieger H, Young CM, Anthenien AM, Neighbors C. The epidemiology of binge drinking among college-age individuals in the United States. Alcohol Res. 2018; 39(1): 23-30.

24. Wolaver A. Does drinking affect grades more for women? Gender differences in the effects of heavy episodic drinking in college. The American Economist. 2007; 51(2): 72-88. https://doi. org/10.1177/056943450705100211

25. Wolaver A. Effects of heavy drinking in college on study effort, grade point average, and major choice. Contemporary Economic Policy. 2002; 20(4): 415-428. https://doi.org/10.1093/cep/20.4.415

26. López-Caneda E, Cadaveira F, Campanella S. Editorial: Binge drinking in the adolescent and young brain. Front Psychol. 2019; 9: 2724. https://doi.org/10.3389/fpsyg.2018.02724

27. Bayles C. The social psychology of college drinking behavior and implications for counseling. Counseling and Wellness: a Professional Counseling Journal. 2013; 4: 1-19.

28. Bandura A. Social cognitive theory. In: Vasta R., editor. Annals of child development. Vol. 6. Six theories of child development. Greenwich: JAI Press; 1989. p. 1-60. 